\title{
Exploring Lenggong Valley World Heritage Site's Brand Equity Dimensions
}

\author{
Shuhaida Md Noor ${ }^{1}$, Haja Mydin Abdul Kuthoos ${ }^{2}$ \\ ${ }^{1,2}$ School of Communication, Universiti Sains Malaysia, 11800 Penang, Malaysia
}

\begin{abstract}
This study explores the brand equity dimensions of a world heritage destination brand, namely the Lenggong Valley World Heritage Site. The study adopted a survey-based brand equity metrics from a previous study that features 27 brand equity dimensions for products. The 27 dimensions were used as the start-off point in exploring the brand equity dimensions for the focal destination brand. The questions were modified to reflect features of heritage destinations. Principal factor analyses were run on data collected from 100 local tourists. The factor analyses yielded 10 factors, namely Trust, Bonding, Service, Acceptability, Value, Heritage, Ambiance, Knowledge, Persistence and Relevance. A new dimension that emerged from the data was value that encompasses both non-financial and financial dimensions.
\end{abstract}

\section{Introduction}

The designation of the UNESCO's World Heritage Site (WHS) title to a heritage site has been suggested to provide distinct advantages in attracting tourists [1-3]. At the time this article was written, there were 1007 sites that have been conferred the title and 1592 sites were in the tentative lists. The WHS 'branding' signifies a site that is worth visiting for its 'outstanding universal value' to those interested in natural and/or cultural heritage. Although from the heritage perspective each of these heritage destination brand has a unique natural or cultural heritage value to offer, from the branding perspective attracting tourists relies on how the brand is ultimately of value to the tourists which may include factors that are not directly related to heritage. Keller [4] explains these values as customer-based brand equity (brand equity henceforth). Knowing the brand equity of a destination brand would greatly help Destination Marketing Organisations (DMOs) at these heritage sites to strategize for their brand.

Ultimately, DMOs strive to create strong brand equity that would result in positive tourists' responses towards the destination. Building the brand equity of heritage sites is imperative in ensuring its competitiveness as a tourist destination and the sites' sustainability in the long run. Brands with strong equity encourage favourable consumer responses such as repeat purchase (or repeat visits in the case of destination brands), strong loyalty and strong emotional attachement [4]. DMOs gain benefits by reducing the site's vulnerability to competitions, building tourists' loyalty and gaining larger profit margins.

In this paper, we explore the brand equity of a world heritage destination. Principal analyses were conducted on a set of brand equity dimensions to reveal the underlying brand equity dimensions of The Lenggong Valley World Heritage Site. The Lenggong Valley World Heritage Site was 
selected in the data collection for this study as it is a relatively new UNESCO's World Heritage Site and is in the nascent stage of its brand development. Insights on the Lenggong Valley World Heritage Site brand equity dimensions would provide specific directions for marketing actions in building its brand equity in the long run. Consequently, the DMOs would be able to know the strengths and weaknesses of the brand which would help them develop specific marketing responses.

\section{Destination Brand and Brand Equity}

Brands are products that have been augmented in some ways to make it different from other similar products [6-8]. In this research, the product in focus is a world heritage destination carrying the brand name Lenggong Valey World Heritage Site (LVWHS). The past ten twenty years have seen an increasing number of research focusing on destination branding as it is viewed to some extent different from products or services. Morrison and Anderson [9] define destination branding as a process of building the unique identity of a destination that distinguishes it from other destinations. Pike [10] suggested that destination branding is more complex than product branding because a destination brand is more multidimensional than product brands, has heterogenous stakeholders, is politically more complex, requires a bottom-up approach that encapsulates community consensus, is hard to measure in terms of its brand loyalty and often faces problems in funding in both scale and consistency. The multidimensional nature of destination brands is of particular interest in this research as it underscores the fact that tourists' responses towards destination brands (e.g. choice of destination to visit, endorsements to others) are affected by dimensions beyond the heritage value alone.

In general terms, brand equity refers to the added value that a brand has on consumers' responses to products compared to their unbranded equivalent [4, 11-12]. These responses, either in the positive or negative direction, is a consequence of what consumers feel, think and do [13] and are reflected in dimensions such as tourists' attachment, perception of relevance, perception on activities at destination and trust. The value added of the brand to a destination, that is its brand equity, may be generated by marketing activities such as brand promotions (e.g. promoting the Lenggong Valley as a world heritage site), brand packaging (e.g. integrating archaeological and non-archaeological attractions) or from consumers' direct experiences with the brand (e.g. visiting the Lenggong archaeological museum).

Several conceptual frameworks for customer-based brand equity have been developed [4, 1112]. Keller's [4] conceptual framework is adopted in this study as it synthesises the work of other previous authors, particularly in the way that brand knowledge has been explained. Building on Aaker's work on brand associations in the consumers' network of memories, Keller provides a detailed description on consumers' information processing by explaining how the brand associative network affects consumers' brand awareness and brand image, the two key dimensions of consumers' brand knowledge. To Keller, brand equity is driven by brand knowledge, represented as a network of brand associations connected to the brand node in memory [4]. The brand associations are formed based on various factors including marketing activities (e.g. advertising), word-of-mouth, or consumers' own experience with the brand - for example, the LVWHS brand node can be connected to associated elements such as 'UNESCO heritage list', 'pre-historic human development' and 'adventure.' To Keller, positive brand equity occurs when the consumer is aware of the brand and holds some strong, favourable and unique brand associations in memory. The customer-based brand equity framework by Keller has been widely advocated and used in research related to destination branding. For example, in line with what has been proposed by Keller, Cai [14] proposed a conceptual model of destination brand that centers on building a destination identity through spreading activation theory [15]. Pike [16] and Boo et al. [17] used the CBBE in developing a measure to evaluate and track the performance of a destination over time. 


\section{Destination Brand Equity Dimensions}

Brand equity is commonly measured through its dimensions in a set of metrics. The dimensions are used to evaluate the 'health' of a brand as it provides information on the dynamics, trends and characteristics of a brand. They are also used to explain various phenomena related to brands such as brand loyalty and brand attachment, and can be used to predict the future performance of the brand. In general, there are three categories of brand dimensions: 1) those that emphasize customers' thoughts and feelings, 2) those that focus on financial-based margins and outcomes, and 3) those that emphasize on marketing communication performance (e.g media coverage and advertising). As brand equity in this research is defined based on the CBBE perspective, the destination brand equity dimensions for this research relate to tourists' evaluation of brand performance based on what they think and feel. Past research reveals various dimensions that could be included as proxy measures for brand equity such as brand awareness, brand leadership, perceived quality and brand image.

A review on past research reveals that one of the most inclusive set of brand equity dimensions that has been developed was by Lehman et. al.[5]. The brand equity dimensions were developed based on brand equity dimensions that have been suggested both by scholars and organisations. The eventual set of dimensions that they proposed are parsimonious in that they are distinct and do not overlap. The 27 dimensions are presented in Table 1.

Table 1. Brand Equity Dimensions from Lehmann et. al [5].

\begin{tabular}{|c|c|}
\hline Dimensions & Source \\
\hline 1. Presence & Millward Brown \\
\hline 2. Awareness & Aaker \\
\hline 3. Knowledge & BAV \\
\hline 4. Relevance & BAV, Millward Brown \\
\hline 5. Difference & BAV \\
\hline 6. Esteem & BAV \\
\hline 7. Performance & $\begin{array}{l}\text { Millward Brown, Research } \\
\text { International }\end{array}$ \\
\hline 8. Advantage & Millward Brown \\
\hline 9. Bonding & $\begin{array}{l}\text { Millward Brown, Research } \\
\text { Internatioanl, Fournier }\end{array}$ \\
\hline 10. Heritage & Research International \\
\hline 11. Trust & Research International \\
\hline 12. Innovation & Research International, BAV \\
\hline 13. Caring & BAV \\
\hline 14. Nostalgia & BAV \\
\hline 15. Prestige & BAV \\
\hline 16. Acceptability & BAV \\
\hline 17. Endorsement & BAV \\
\hline 18. Quality & Ambler \\
\hline 19. Ambiance & Ambler \\
\hline 20. Service & Ambler \\
\hline 21. Loyalty & Keller \\
\hline 22. Intention & Keller \\
\hline 23. Value for Money & Keller \\
\hline 24. Overall Attitude & Research International \\
\hline 25. Extension Potential & Keller \& Lehmann \\
\hline 26. Persistence & Fournier \\
\hline 27. Activity & Keller \\
\hline
\end{tabular}




\section{Methodology}

\subsection{Sampling}

The target population for this study is domestic tourists who visited the LVWHS. While systematic random sampling is preferred, due to the time constraint and low number of visitors during the period of data collection, convenience sampling technique was utilised instead. Data was collected from domestic tourists who visited the Lenggong Valley Archaeological Museum. The Lenggong Archaeological Museum is a 'must-visit' site for tourists, hence, allowing us to approach the most number of tourists to the Lenggong World Heritage Site. The tourists were approached at the exit of the Lenggong Archaeological Museum. The tourists were asked to fill up the questionnaire and return the questionnaire to the administrator immediately upon completion. At the end of the three-day data collection period, 100 usable questionnaires were collected.

\subsection{Instrument}

The questionnaire was developed based on the brand equity dimensions for products developed by Lehmann et. al [5]. The 27 product brand dimensions have been validated by the authors for various different products in different countries and reflects dimensions that have been proposed both by scholars in the academics and the industry. In this preliminary study our aim is to explore the brand equity dimensions for a world heritage destination. The 27 dimensions served as the start-off point to explore the underlying brand equity dimensions for destinations.

The questionnaire consisted of two major sections. The first section included questions relating to the demographic profile of the respondents. The second section featured questions on the 27 brand equity dimensions. The items for each dimension were adapted from the original survey questionnaire by Lehmann et. al [5] with changes made to ensure that they were reflective of world heritage destination brands. The questions were developed both in English and Malay. A pilot test was conducted to assess how well the questions captured the dimensions that it was supposed to measure. Data for the pilot test was collected from 50 domestic tourists to the Lenggong Valley World Heritage Site. Following a reliability test with a rule of thumb of 0.7 lower limit for the Cronbach's alpha, the questionnaire was modified (i.e. omitting some questions) to ensure the internal consistency and reliability of the questionnaire items.

\subsection{Data analysis}

Principal component analyses were utilised to explore the underlying brand equity dimensions of the LVWHS.

\section{Results and Discussion}

A test on the suitability of data for factor analyses revealed the presence of many coefficients of 0.3 and above. The Kaiser-Meyer-Olkin value was .644, exceeding the recommended value of .6. The Bartlett's Test of Sphericity yielded a statistical significance. A principal component analysis with orthogonal (VARIMAX) rotation was utilised to explore the underlying brand equity dimensions of LVWHS.

Based on the eigenvalue greater than 1, scree-plot observation and the percentage of the variance criterion, ten factors were chosen capturing $65.25 \%$ of the total variance. Items with factor loadings that were less than .4 , and those that do not load on any factors were dropped. The results of the component analysis with orthogonal rotations are shown in Table 2. 
Table 2. Underlying Brand Equity Dimensions for Lenggong Valley World Heritage Site

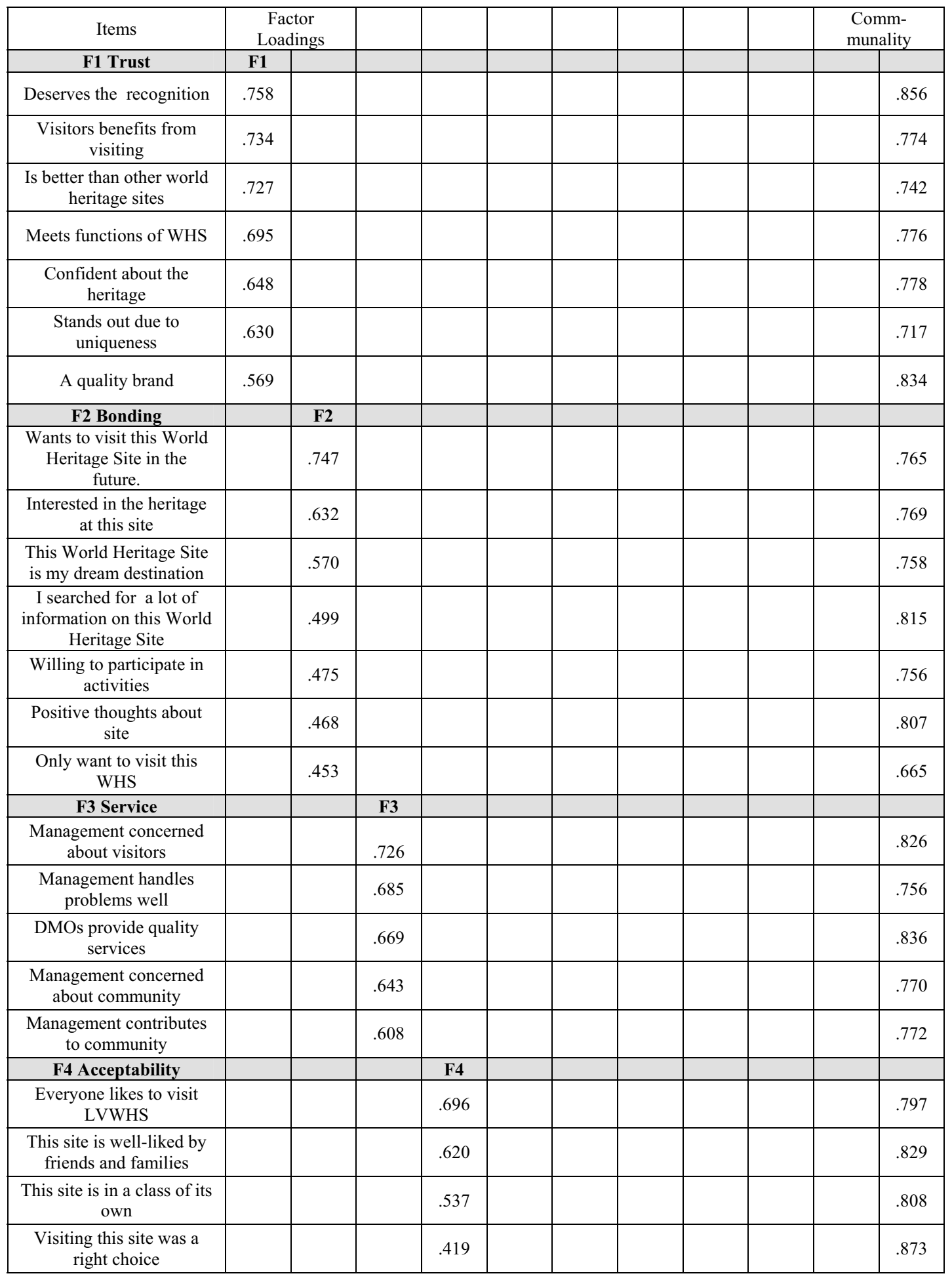


SHS Web of Conferences

\begin{tabular}{|c|c|c|c|c|c|c|c|c|c|c|c|}
\hline F5 Value & & & & & F5 & & & & & & \\
\hline Great value for money & & & & & .758 & & & & & & .806 \\
\hline Provides great satisfaction & & & & & .696 & & & & & & .821 \\
\hline High heritage value & & & & & .589 & & & & & & .808 \\
\hline F6 Heritage & & & & & & F6 & & & & & \\
\hline $\begin{array}{l}\text { Offers new insights on } \\
\text { heritage }\end{array}$ & & & & & & .733 & & & & & .798 \\
\hline $\begin{array}{l}\text { Heritage has been around } \\
\text { for a long time }\end{array}$ & & & & & & .655 & & & & & .854 \\
\hline The site has a long history & & & & & & .640 & & & & & .827 \\
\hline F7 Ambiance & & & & & & & F7 & & & & \\
\hline $\begin{array}{l}\text { Has a friendly } \\
\text { community. }\end{array}$ & & & & & & & .703 & & & & .722 \\
\hline $\begin{array}{c}\text { Comfortable at this World } \\
\text { Heritage Site. }\end{array}$ & & & & & & & .651 & & & & .773 \\
\hline $\begin{array}{c}\text { Natural surroundings at } \\
\text { this World Heritage Site } \\
\text { attracts my interest. }\end{array}$ & & & & & & & .494 & & & & .818 \\
\hline F8 Knowledge & & & & & & & & F8 & & & \\
\hline $\begin{array}{l}\text { Know of interesting } \\
\text { features }\end{array}$ & & & & & & & & .659 & & & .836 \\
\hline $\begin{array}{l}\text { In-depth knowledge of } \\
\text { LVWHS }\end{array}$ & & & & & & & & .615 & & & .853 \\
\hline $\begin{array}{l}\text { Wide knowledge on } \\
\text { LVWHS }\end{array}$ & & & & & & & & .569 & & & .811 \\
\hline F9 Persistence & & & & & & & & & F9 & & \\
\hline $\begin{array}{c}\text { Continue to support } \\
\text { despites its imperfections }\end{array}$ & & & & & & & & & .635 & & .837 \\
\hline $\begin{array}{l}\text { Willing to forgive for } \\
\text { poor service }\end{array}$ & & & & & & & & & .549 & & .847 \\
\hline $\begin{array}{l}\text { Unlikely to change } \\
\text { opinion about the site }\end{array}$ & & & & & & & & & .446 & & .821 \\
\hline F10 Relevance & & & & & & & & & & F10 & \\
\hline $\begin{array}{l}\text { This World Heritage Site } \\
\text { has a heritage that is } \\
\text { relevant to me }\end{array}$ & & & & & & & & & & .611 & .852 \\
\hline $\begin{array}{l}\text { has a heritage that is } \\
\text { relevant to my families } \\
\text { and friends }\end{array}$ & & & & & & & & & & .681 & .849 \\
\hline Eigenvalue & 11.6 & 6.4 & 5.8 & 5.5 & 5.5 & 4.4 & 4.3 & 4.3 & 3.0 & 2.7 & \\
\hline Variance & 14.1 & 7.7 & 7.1 & 6.8 & 6.7 & 5.4 & 5.2 & 5.2 & 3.7 & 3.3 & \\
\hline Cumulative variance & 14.1 & 21.9 & 28.9 & 35.7 & 42.4 & 47.8 & 53.0 & 58.2 & 61.9 & 65.3 & \\
\hline Cronbach's alpha & .92 & .84 & .89 & .86 & .86 & .84 & .85 & .83 & .76 & .70 & \\
\hline
\end{tabular}

The principal component analysis yielded 10 dimensions that are reflective of destination brand equity. The dimensions are as follows: Trust, Bonding, Service, Acceptability, Value, Heritage, Ambiance, Knowledge, Persistence and Relevance. A new dimension that emerged from the data was value, which was found to be distinctly different from the idea of value for money that was included in the original brand equity dimensions for product. In the case of heritage site, value was reflected in a more general sense that include both the financial value and non-financial value. The following section discusses each of the dimensions. 


\subsection{Trust}

The dimension trust reflects the tourists' faith in the authenticity and significance of the heritage at the site. One approach to gain trust among tourists is by providing proof of authentication from authorised sources. In the case of the Lenggong Valley World Heritage Site, the proof comes in the form of the entitlement of the site as a UNESCO World Heritage site.

\subsection{Bonding}

Bonding refers to the emotional and personal attachment that tourists developed with the site. A bonding with the site would be a pre-requisite for a long term relationship that may lead to revisitations, endorsements to others and long-term support for efforts to conserve the site.

\subsection{Service}

Service refers to tourism services such as accommodation and tourist guide services, as well as public services such as toilets and public transports. The quality of services at the tourist sites relates to the tourists' quality of stay and experience at the site. Like many archaeological heritage sites, the Lenggong Valley World Heritage Site is situated in a remote area with intermittent public transport that connects the site to bigger townships or cities, such as Penang or Ipoh, where most tourists are concentrated. Those visiting the site would need their own public transport or charter a transport. As for accommodations, being a new tourism destination, Lenggong Valley has yet to have high quality hotels. The available homestays, however, could be an attraction in itself for tourists who are looking for a difference.

\subsection{Acceptability}

The acceptability dimension allows one to gauge whether tourists agree that the site fits with their perception of what a heritage tourist destination should be, and that it is in general has been recognised by the public as a tourist destination. The acceptability dimension is an interesting dimension in that it reveals that tourists' evaluation of a site is influenced by their perception of whether or not a destination has been 'officially' and widely recognised as a tourist destination. The findings indicate that in promoting a heritage site, it is important to focus on recognitions that the site has received such as the World Heritage Site title or even citing the endorsements of tourists who have had a positive experience at the site.

\subsection{Value}

Interestingly, the dimension value that emerged from the data reflect a more encompassing idea of value rather than the one suggested in the original product brand equity dimensions. Value here refers more to how the tourists appreciate the heritage at the site from non-financial aspects, such as how the much the heritage means to them as individuals and as Malaysians, particularly because the heritage has been declared as a World Heritage.

\subsection{Heritage}

For a heritage destination, the heritage dimension should be a focus as heritage is the main attraction of the site. The key areas that require focus is the tourists perception on the authenticity of the heritage, its contribution to their knowledge of human development or civilisation, and how the site is different or unique compared to other heritage sites. Interestingly, heritage also refers to how long the site has been recognised as a heritage site destination, either unofficially or officially. 


\subsection{Ambiance}

Ambiance refers to the tourists' evaluation on the "look and feel" of the site based elements such as the natural environment, the built environment, the available facilities and their interaction with service providers and the local community. It is important to note that for this dimension, the whole is bigger than the sum of its parts, that is, the evaluation would be based on the overall evaluation rather than the individual elements. The ambiance is highly related with tourists' their level of satisfaction after the visit.

\subsection{Knowledge}

As expected, the data revealed that knowledge is one of the ten key dimensions of destination brand equity. The knowledge dimension is particularly important for heritage sites as many tourists visit heritage sites with knowledge as their primary motivation. Keller [4] has proposed that brand associations, the building blocks of brand knowledge, are the repository of information that are evaluated in terms of their strength, uniqueness and favourability. Brands that are likely to have strong brand equity are those with associations that are top-of-mind or those that are easily recognized, unique in that they become the differentiating factor if compared to similar brands, and are favourable in that they are likely to bring positive evaluation or high desirability.

\subsection{Persistence}

The persistence dimension reflects tourists' continuous support for the site and as such is a good indicator for the sustainability of the site as a tourist attraction. The dimension reflects tourists' readiness to endorse the site to others and their willingness to accept flaws because they believe the benefits of the site outweigh those flaws. The dimension in a way reflects the tourists' conviction in what the site has to offer.

\subsection{Relevance}

Relevance relates to the extent that tourists perceive the site is pertinent to them, such as how it relates to their own cultural or social background. It is also about the relevance of the site is to their motivations in visiting their site. Relevance could be a challenge for an archaeological site like Lenggong that features artefacts that can be traced back to the pre-historic age. Visitors may find it difficult in connecting to events that happen in the pre-historic age. In understanding the heritage, visitors are often challenged to visualise the flora, fauna, geographic environement and lifestyles of more than a million years old.

\section{Conclusion}

The study was conducted to explore the brand equity dimensions that could be used as proxy measures for the performance of a world heritage destination brand. Twenty seven brand equity dimensions of products were used as the start-off point. A survey questionnaire was used to collect data on tourists' evaluation of the Lenggong Valley World Heritage Site. Principal factor analyses that were run based on data collected from 100 local tourists yielded ten factors, namely Trust, Bonding, Service, Acceptability, Value, Heritage, Ambiance, Knowledge, Persistence and Relevance. These dimensions were found to be key in local tourists' perceptions of a heritage destination. Nevertheless, we acknowledge that the factors were based on the perception of a limited number (100) local tourists. For a World Heritage Destination like the Lenggong Valley World Heritage Site, the perceptions of international tourists, one of the key stakeholders, are imperative. More data are also required for more definitive results. 
4ICTR

\section{References}

1. R. Buckley, J. Sustainable Tourism.12, 70 (2004).

2. A. Fyall and T. Rakic, Managing world heritage sites.(2006)

3. Y. Poria, A. Reichel, R. Cohen, J. Travel Research. 50, 482 (2011)

4. K. Keller, Strategic management: building, measuring and managing brand equity. (1998)

5. D. Lehmann, K. Keller, J. Farley, J. of International Marketing, 16, 29 (2008)

6. J. Aaker. J. Marketing Research, 36, 45 (1999)

7. J Kapferer, Strategic brand management: creating and sustaining brand equity long term (1999)

8. K. Keller, (2003), J. Consumer Research, 29, 595 (2003).

9. A. Morrison and D. Anderson, Missouri Association of Convention \& Visitor Bureaus Annual Meeting, (2002).

10. S. Pike, J. Product \& Brand Management, 14, 258 (2005)

11. D. Aaker, Managing brand equity (1991)

12. P. Farquhar, J. of Advertising Research, 30, RC7 (1990)

13. T. Ambler, Marketing and The Bottom Line (2003)

14. L. Cai. Annals of Tourism Research, 29, 720 (2002)

15. J. Anderson, The architecture of cognition (1983)

16. S. Pike, J. Travel \& Tourism Marketing, 22, 51 (2007)

17. S. Boo, J Busser, S. Baloglu, Tourism Management, 30, 219 (2009) 